\title{
Anticancer mechanisms of Strobilanthes crispa Blume hexane extract on liver and breast cancer cell lines
}

\author{
RHUN YIAN KOH ${ }^{1}$, FOONG PING LIM ${ }^{2}$, LESLIE SIING YIE LING ${ }^{2}$, CATHERINE PEI LING NG ${ }^{3}$, \\ SIEW FOONG LIEW ${ }^{3}$, MEI YENG YEW ${ }^{4}$, YEE LIAN TIONG ${ }^{5}$, ANNA PICK KIONG LING ${ }^{1}$, \\ SOI MOI CHYE ${ }^{1}$ and KHUEN YEN NG ${ }^{4}$
}

\author{
${ }^{1}$ Division of Applied Biomedical Science and Biotechnology, School of Health Sciences; ${ }^{2}$ Pharmacy Program, \\ School of Pharmacy; ${ }^{3}$ Biomedical Science Program, School of Health Sciences, International Medical \\ University, Bukit Jalil, 57000 Kuala Lumpur; ${ }^{4}$ Jeffrey Cheah School of Medicine and Health Sciences, \\ Monash University Malaysia, Jalan Lagoon Selatan, Bandar Sunway, 47500 Selangor; ${ }^{5}$ School of Postgraduate \\ Studies and Research, International Medical University, Bukit Jalil, 57000 Kuala Lumpur, Malaysia
}

Received October 21, 2015; Accepted March 23, 2017

DOI: $10.3892 / 01.2017 .6821$

\begin{abstract}
Cancer is a major public health concern not only in developed countries, but also in developing countries. It is one of the leading causes of mortality worldwide. However, current treatments may cause severe side effects and harm. Therefore, recent research has been focused on identifying alternative therapeutic agents extracted from plant-based sources in order to develop novel treatment options for cancer. Strobilanthes crispa Blume is a plant native to countries including Madagascar and Indonesia. It has been used as an anti-diabetic, diuretic and laxative in traditional folk medicine. Furthermore, S. crispa has potential in treating cancer, as evidenced in previous studies. In the present study, the cytotoxic and apoptotic activities of $S$. crispa crude extracts were investigated in liver and breast cancer cell lines. Hexane, ethyl acetate, chloroform, methanol and water extracts prepared from the leaves, and stems of S. crispa were evaluated for their cytotoxicity on HepG-2 and MDA-MB-231 cells using an MTT assay. The anti-proliferative properties of stem hexane (SH) extract on both cell lines were analysed using cell doubling time determination and cell cycle analysis, while the apoptogenic properties was determined through the detection of caspase-8. Among the extracts tested, $\mathrm{SH}$ extract exhibited the lowest half maximal inhibitory concentrations in both the cell lines. The SH extract induced morphological changes in HepG-2 and MDA-MB-231 cells, and significantly delayed
\end{abstract}

Correspondence to: Dr Rhun Yian Koh, Division of Applied Biomedical Science and Biotechnology, School of Health Sciences, International Medical University, 126, Jalan Jalil Perkasa 19, Bukit Jalil, 57000 Kuala Lumpur, Malaysia

E-mail: rhunyian_koh@imu.edu.my

Key words: anticancer, apoptosis, Strobilanthes crispa Blume, liver cancer, breast cancer cell population doubling time. Furthermore, it altered cell cycle profile and significantly increased caspase- 8 activity in HepG-2 cells, but not in MDA-MB-231 cells. In conclusion, the SH extract of $S$. crispa possesses potent anticancer properties and may be a suitable chemotherapeutic target.

\section{Introduction}

Cancer is characterized by uncontrolled growth and spreading of abnormal cells. It is one of the most life-threatening and challenging diseases of modern time, caused by a number of internal factors, including immune condition and inherited mutation, and external factors, including radiation, tobacco and chemical exposure (1). Liver, breast, colorectal, lung, cervical and nasopharyngeal cancer are the most prevalent cancer types in the modern age. The present study focused on liver and breast cancer due to their high occurrence rates. In 2006, hepatocellular carcinoma (HCC) was identified to account for $70-85 \%$ of total primary liver cancer types (2). HCC is primarily caused by chronic viral hepatitis $\mathrm{B}$ or $\mathrm{C}$ infection, iron overload, aflotoxin exposure, obesity, alcohol-associated cirrhosis and possibly non-alcoholic fatty liver disease $(3,4)$. Breast cancer continues to be the leading cause of cancer-associated mortality among women (5), and the occurrence rate has increased in China and other Asian countries $(6,7)$. Breast cancer can be categorized into two main types, ductal carcinoma and lobular carcinoma. Ductal carcinoma begins in the ducts that transport milk from the breast to the nipple, whereas lobular carcinoma starts in the lobules that produce milk. Atypical hyperplasia of the breast, family history, early menarche, late menopause and Li-Fraumeni syndrome are some of the known risk factors for breast cancer (8-10).

To date, the common treatments for cancers are surgical removal of the tumour tissue, chemotherapy and ionizing radiation. Apart from destroying adjacent normal cells (11), these treatments also cause severe side effects (12-14). Therefore, current studies have focused on the search for alternative medicines from plant-based sources. Alternative medicine 
not only improves the efficacy of conventional medicines, it reduces the side effects of chemotherapy (15) and strengthens the immune system to fight against cancer (16).

Among the medicinal plants, one of the commonly found plants in tropical countries is Strobilanthes crispa Blume. It is traditionally known as daun pecah beling in Jakarta and enyoh kilo, kecibeling or kejibeling in Java (17). In Malaysia, it is known as pecahkaca or jinbatu (17). This bush-like plant is scattered throughout the regions of Madagascar to Malay Archipelago (18). S. crispa has high mineral and phenolic content, and exhibits high antioxidant activity (19,20). In addition, this plant contains alkaloids, tannins, polyphenols, water-soluble vitamins, caffeine, catechins $(19,20)$ and bioactive compounds, including $\beta$-sitosterol, and stigmasterol (21). A previous study demonstrated that $S$. crispa leaves possess anti-diabetic, diuretic and blood pressure lowering properties (17). Furthermore, a number of studies have recorded the potency of $S$. crispa extracts in inhibiting cancer cell growth (22-25).

Thus, the aim of the present study was to investigate the cytotoxic and anti-proliferative effects of S. crispa extracts on HepG-2 and MDA-MB-231 cancer cell lines. Furthermore, one of the aims was to determine the effects of the extracts on cell cycle and caspase- 8 activation.

\section{Materials and methods}

Preparation of plant extracts. The botanical identity of $S$. crispa was determined and authenticated by a taxonomist from the Forest Research Institute Malaysia (Kuala Lumpur, Malaysia; sample no. PID 040114-04). Fresh plant materials (leaves and stems) were collected and dried in an oven at $40^{\circ} \mathrm{C}$ until a constant weight was obtained. Dried leaves and stems were separated, crushed into fine pieces and then ground with a mill grinder into powder form. A total of four organic solvent extracts of the leaves and stems were prepared individually. The organic solvents used were hexane, chloroform, ethyl acetate and methanol (all Friendemann Schmidt, Parkwood, WA, USA). The extraction was performed by mixing $500 \mathrm{ml}$ of solvent into $100 \mathrm{~g}$ of powdered leaves or stems, and then macerating in the dark at room temperature for 3 days. The suspensions were filtered using Whatman paper (Thermo Fisher Scientific, Inc., Waltham, MA, USA) and then evaporated using a rotary evaporator (Büchi R-2154; Büchi Labortechnik AG, Flawil, Switzerland) to obtain desired crude extracts. The extracts obtained were as follows: Leaf hexane (LH), leaf chloroform (LC), leaf ethyl acetate (LEA), leaf methanol (LM), stem hexane (SH), stem chloroform (SC), stem ethyl acetate (SEA) and stem methanol (SM).

The dried plant materials $(10 \mathrm{~g})$ were mixed with $500 \mathrm{ml}$ distilled water and kept at $60^{\circ} \mathrm{C}$ for $3 \mathrm{~h}$. The resulting suspensions were then filtered and followed by freeze drying. The extracts obtained were designated as leaf water (LW) and stem water $(\mathrm{SW})$.

Cell culture. Hepatocellular carcinoma HepG-2, breast cancer MDA-MB-231 and normal rat kidney NRK-52E cell lines were obtained from the American Type Culture Collection (Manassas, VA, USA). The cells were cultured in Dulbecco's modified Eagle medium (DMEM) supplemented with $10 \%$ fetal bovine serum (FBS), $100 \mathrm{U} / \mathrm{ml}$ penicillin and $100 \mathrm{mg} / \mathrm{ml}$ streptomycin (all Gibco; Thermo Fisher Scientific, Inc.), and maintained at $37^{\circ} \mathrm{C}$ in a humidified atmosphere of $5 \% \mathrm{CO}_{2}$.

MTT assay. HepG-2, MDA-MB-231 and NRK-52E cells were seeded at a density of $1 \times 10^{5}$ cells $/ \mathrm{ml}$ into a $96-$ well plate and treated with varying concentrations of $S$. crispa extracts $(12.5$, 25, 50, 100 and $200 \mu \mathrm{g} / \mathrm{ml}$ ) including LH, LC, LEA, LM, LW, $\mathrm{SH}, \mathrm{SC}, \mathrm{SEA}, \mathrm{SM}$ and $\mathrm{SW}$ for $72 \mathrm{~h}$ at $37^{\circ} \mathrm{C}$. Subsequently, $10 \mu 1$ MTT solution (Bio Basic, Inc., Amherst, NY, USA) was added into each well and cells were incubated for $4 \mathrm{~h}$ at $37^{\circ} \mathrm{C}$. Subsequently, the solution in each well was removed and $100 \mu \mathrm{l}$ of dimethyl sulphoxide (Friendemann Schmidt) was added. The coloured solution was measured using a Dynex Opsys MR microplate reader (Dynex Technologies Inc., Chantilly, VA, USA) at $570 \mathrm{~nm}$ wavelength. Cell viability (\%) was calculated according to the following formula: Optical density (OD) of samples/OD of control x100, where the control represents untreated cells. The control cells were incubated with DMEM supplemented with $10 \% \mathrm{FBS}, 100 \mathrm{U} / \mathrm{ml}$ penicillin and $100 \mathrm{mg} / \mathrm{ml}$ streptomycin (all Gibco; Thermo Fisher Scientific, Inc.) for $72 \mathrm{~h}$ at $37^{\circ} \mathrm{C}$. The half maximal inhibitory concentration $\left(\mathrm{IC}_{50}\right)$, which is defined as the concentration required to inhibit cell viability by $50 \%$, was determined through the construction of a dose-response curve.

HepG-2 and MDA-MB-231 cells were also treated with 5-flurouracil (5-Fu; Sigma-Aldrich; Merck KGaA, Darmstadt, Germany), the positive control of the experiment, at the concentrations of $12.5,25,50,100$ and $200 \mu \mathrm{g} / \mathrm{ml}$ for $72 \mathrm{~h}$ at $37^{\circ} \mathrm{C} . \mathrm{IC}_{50}$ values were determined and the cytotoxicity of S. crispa extracts were compared to the effects of the known anti-cancer drug, 5-Fu.

The selectivity index (SI) in the present study was calculated from the $\mathrm{IC}_{50}$ of the extracts in normal rat kidney cells (NRK-52E) vs. cancer cells. The extract was considered to have high selectivity for cancer cells if the SI was $>3$ (26).

Observation of morphological changes. HepG-2 and MDA-MB-231 cells were seeded at a density of $1 \times 10^{6}$ cells/well into 6-well plates and treated with the $\mathrm{SH}$ at their respective $\mathrm{IC}_{50}$ concentrations for $72 \mathrm{~h}$ at $37^{\circ} \mathrm{C}$. Untreated and treated cells were then observed under an inverted microscope (Nikon Eclipse TS100; Nikon Corporation, Tokyo, Japan) and images were captured with the attached camera.

Determination of cell doubling time. HepG-2 and MDA-MB-231 cells were seeded into a 24-well plate at the density of $1 \times 10^{4}$ cells $/ \mathrm{ml}$. Subsequently, the cells were treated with $\mathrm{SH}$ and incubated at $37^{\circ} \mathrm{C}$ for $72 \mathrm{~h}$. Two different concentrations were used: The pre-determined $\mathrm{IC}_{50}$; and $2 \mathrm{x}$ the $\mathrm{IC}_{50}$. On the third day, the treated cells were trypsinised and stained with trypan blue (Gibco; Thermo Fisher Scientific, Inc.). Live cells were counted under an inverted microscope (Nikon Eclipse TS100) using a hemocytometer (Paul Marienfeld GmbH \& Co. KG, Lunda-Königshofen, Germany). The cell doubling time was calculated by dividing the total duration (h) by the total number of generations. The number of generations was calculated using the following formula: 3.32 $\left(\log \mathrm{N}_{\mathrm{N}}-\log \mathrm{N}_{1}\right)$, where $\mathrm{N}_{\mathrm{N}}$ is the number of cells counted and $\mathrm{N}_{1}$ is the number of cells seeded (27). 


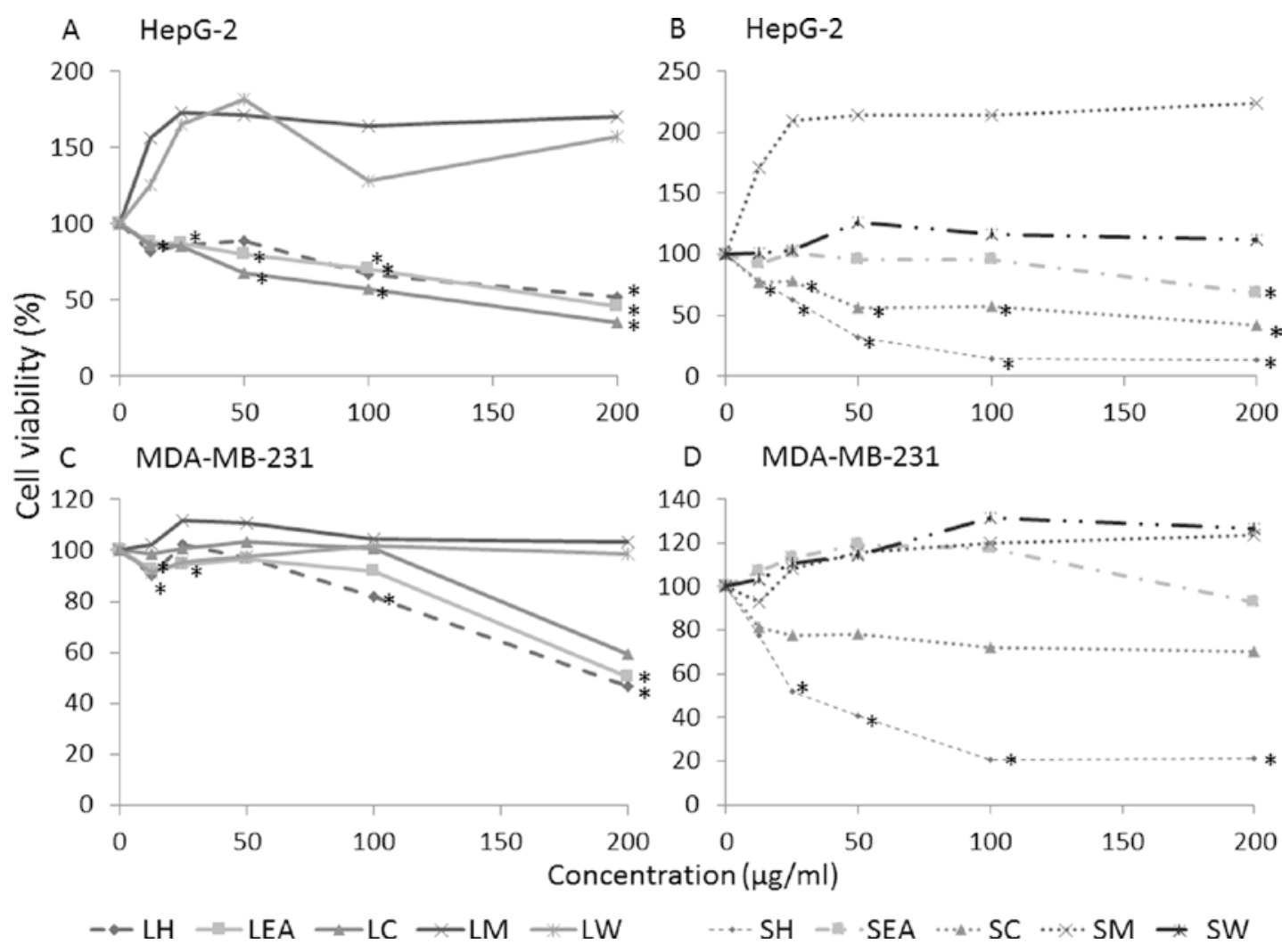

Figure 1. Dose-response curve of Strobilanthes crispa extracts on HepG-2 liver cancer and MDA-MB-231 breast cancer cell lines. Cells were treated with various concentrations $(12.5,25,50,100$ and $200 \mu \mathrm{g} / \mathrm{ml})$ of $S$. crispa extracts for $72 \mathrm{~h}$ and percentage of cell viability was determined using an MTT assay. HepG-2 cells treated with extracts derived from the (A) leaves and (B) stems of Strobilanthes crispa. MDA-MB-231 cells treated with extracts derived from the (C) leaves and (D) stems of Strobilanthes crispa. Data are presented as the mean following 3 independent experiments. "P<0.05, compared with the untreated control (representing 100\% of cell viability). LH, leaf hexane; LEA, leaf ethyl acetate; LC, leaf chloroform; LM, leaf methanol; LW, leaf water; SH, stem hexane; SEA, stem ethyl acetate; SC, stem chloroform; SM, stem methanol; SW, stem water.

Cell cycle analysis. HepG-2 and MDA-MB-231 cells were seeded into 6 -well plates at a density of $1 \times 10^{6}$ cells/well and treated with $\mathrm{SH}$ at $\mathrm{IC}_{50}$ for $72 \mathrm{~h}$ at $37^{\circ} \mathrm{C}$. The cells were fixed with $70 \%$ ethanol subsequently. Then the cells were washed twice with cold phosphate buffer saline (PBS) and resuspended in $1 \mathrm{ml}$ of PBS at a concentration of $1 \times 10^{6} \mathrm{cell} / \mathrm{s} / \mathrm{ml}$. Subsequently, $5 \mu \mathrm{l}$ of $10 \mathrm{mg} / \mathrm{ml}$ RNase (Sigma-Aldrich; Merck KGaA) was added to the cell suspension and incubated at $37^{\circ} \mathrm{C}$ for $1 \mathrm{~h}$. Subsequently, $10 \mu \mathrm{l}$ propidium iodide ( $1 \mathrm{mg} / \mathrm{ml}$; Sigma-Aldrich; Merck KGaA) was added and the suspension was incubated in the dark for $30 \mathrm{~min}$ at $37^{\circ} \mathrm{C}$. Finally, the samples were analysed using flow cytometry (FACScan; BD Biosciences, Franklin Lakes, NJ, USA) and CELLQuest ${ }^{\mathrm{TM}}$ software (BD Biosciences), version 3.0. Flow cytometric analysis of the samples stained with propidium iodide was run by collecting 25,000 events per sample.

Detection of caspase- 8 . The caspase- 8 assay kit was purchased from Calbiochem (Merck KGaA). The caspase activity in $\mathrm{SH}$-treated cells was measured according to the manufacturer's protocol. Briefly, cells were seeded at a density of $1 \times 10^{6}$ cells $/ \mathrm{ml}$ into 6-well plates. Cells were trypsinised following treatment with the $\mathrm{SH}$ at $\mathrm{IC}_{50}$ for $72 \mathrm{~h}$ at $37^{\circ} \mathrm{C}$. The cells were then transferred into an Eppendorf tube. Subsequently, $1 \mu 1$ staining reagent was added to the cell suspension and incubated at $37^{\circ} \mathrm{C}$ for $30 \mathrm{~min}$. Cells were washed with PBS and transferred into a black well plate. Fluorescence intensity at excitation $485 \mathrm{~nm}$ and emission $535 \mathrm{~nm}$ was then recorded.
Statistical analysis. Statistical analysis was performed using one-way analysis of variance with Tukey's honest significant difference post-hoc test with GraphPad Instat software (version 3.0; GraphPad Software, Inc., La Jolla, CA, USA) or Student's t-tests with Microsoft Excel (version 2013; Microsoft Corporation, Redmond, WA, USA). All data are presented as the mean \pm standard deviation. $\mathrm{P}<0.05$ was considered to indicate a statistically significant difference.

\section{Results}

Cytotoxic effect of S. crispa extracts. The effect of $S$. crispa on the growth activities of HepG-2 and MDA-MB-231 cells was investigated using MTT assays (Fig. 1). In total, 5 extracts (LH, LC, LEA, SH and SC) were demonstrated to induce cell death in the two cell lines in a concentration-dependent manner $(\mathrm{P}<0.05)$ while SEA displayed moderate cytotoxicity. However, methanolic and water extracts of S. crispa (LM, LW, SM and SW) revealed no evident cytotoxic activity against the cell lines. In fact, the extracts promoted the growth of cancer cells, when compared with the untreated control (Fig. 1). However, the differences were not statistically significant.

Based on the dose-response curve generated, $\mathrm{IC}_{50}$ of each extracts was determined and summarized in Table I. Among the extracts tested, SH exhibited the highest potency with the lowest $\mathrm{IC}_{50}$ values in mediating HepG-2 and MDA-MB-231 cell death. The $\mathrm{IC}_{50}$ value obtained from HepG-2 cells 
(38.8 $\mu \mathrm{g} / \mathrm{ml})$ was comparable to the commercially available anti-cancer drug, 5 -Fu ( $\left.\mathrm{IC}_{50}, 37.3 \mu \mathrm{g} / \mathrm{ml}\right)$. The $\mathrm{IC}_{50}$ determined in MDA-MB-231 cells, $42.5 \mu \mathrm{g} / \mathrm{ml}$ was 1.4 times lower compared with the $5-\mathrm{Fu}\left(\mathrm{IC}_{50}, 60 \mu \mathrm{g} / \mathrm{ml}\right)$.

SI calculated based on predetermined $\mathrm{IC}_{50}$ values on NRK-52E cells demonstrated that none of the extracts, apart from SC, exhibited high selectivity towards cancer cells because the SI values were $<3$ (Table I). Furthermore, the anti-cancer drug, 5-Fu exhibited poor selectivity. The SI value of SC was markedly higher compared with the other extracts $(>1.15)$.

Effect of SH on cell morphological changes. HepG-2 and MDA-MB-231 cells were observed under an inverted microscope for morphological changes and the results are presented in Fig. 2. Fig. 2A demonstrates confluent HepG-2 cells that are flattened, grossly polygonal in shape and arranged in monolayer. In the SH-treated HepG-2 cells, morphological changes, including the formation of vacuoles within the cell were observed. Furthermore, floating dead cells and a reduction in cell number were also noted (Fig. 2B).

SH also induced MDA-MB-231 cell death as more floating cells were observed in the treated compared with the control cells. Untreated MDA-MB-231 cells remained normal, healthy and confluent throughout the treatment period (Fig. 2C). However, vacuolation of cells was noted in the treated cells (Fig. 2D).

Effect of SH on cell doubling time. Fig. 3 demonstrates the effect of SH on HepG-2 and MDA-MB-231 cell proliferation. When HepG-2 cells were exposed to $\mathrm{SH}$ at the $\mathrm{IC}_{50}$, no significant differences in the cell population doubling time were observed. However, cells treated with double the $\mathrm{IC}_{50}$ of $\mathrm{SH}$ exhibited a significant increase in the cell doubling time compared with the untreated control group $(\mathrm{P}<0.001)$. However, MDA-MB-231 cells responded to $\mathrm{SH}$ in a dose-dependent manner. SH treatment at the $\mathrm{IC}_{50}$ caused a 2.5 -fold delay in cell proliferation while twice the $\mathrm{IC}_{50}$ of $\mathrm{SH}$ delayed cell doubling by 3.4 -fold. The delayed cell doubling in cells treated with the higher dose was statistically significant when compared with the untreated control cells $(\mathrm{P}<0.05)$.

Effect of SH on cell cycle profile. Treatment with $\mathrm{SH}$ caused HepG-2 cell cycle arrest at the $G_{0} / G_{1}$ phase. This in turn caused a decrease in percentage of cells that entered the $\mathrm{S}$ and $\mathrm{G}_{2} / \mathrm{M}$ phases. The percentage of cells in sub-G phase in $\mathrm{SH}$-treated group was $\sim 50 \%$ compared with that of the control cells (Table II).

Table III shows the distribution of MDA-MB-231 cells in different cell cycle phases following treatment with $\mathrm{SH}$. Increased sub-G and $\mathrm{S}$ phases were noted following the treatment; however, no significant differences were identified.

Effect of SH on caspase-8 activation. SH treatment significantly induced caspase- 8 activation in $\mathrm{HepG}-2$ cells $(\mathrm{P}<0.01)$. $\mathrm{SH}$ treatment appeared to induce caspase- 8 activation in MDA-MB-231 cells, although this was not significant (Fig. 4).

\section{Discussion}

Cancer remains one of the leading causes of mortality worldwide. The limited success of current therapies is evident
Table I. $\mathrm{IC}_{50}$ and SI values of extracts of Strobilanthes crispa on HepG-2 and MDA-MB-231 cells.

\begin{tabular}{lcc}
\hline & \multicolumn{2}{c}{$\mathrm{IC}_{50}, \mu \mathrm{g} / \mathrm{ml}(\mathrm{SI})$} \\
\cline { 2 - 3 } Extract/treatment & HepG-2 & MDA-MB-231 \\
\hline Leaf & & \\
Hexane & $\mathrm{N} / \mathrm{A}$ & $192.50 \pm 3.54(0.44)$ \\
Chloroform & $175.70 \pm 35.40(1.05)$ & $\mathrm{N} / \mathrm{A}$ \\
Ethyl acetate & $176.70 \pm 15.30(0.94)$ & $\mathrm{N} / \mathrm{A}$ \\
Methanol & $\mathrm{N} / \mathrm{A}$ & $\mathrm{N} / \mathrm{A}$ \\
Water & $\mathrm{N} / \mathrm{A}$ & $\mathrm{N} / \mathrm{A}$ \\
Stem & & \\
Hexane & $38.80 \pm 8.50(0.28)$ & $42.50 \pm 39.67(0.26)$ \\
Chloroform & $173.30 \pm 5.80(>1.15)$ & $\mathrm{N} / \mathrm{A}$ \\
Ethyl acetate & $\mathrm{N} / \mathrm{A}$ & $\mathrm{N} / \mathrm{A}$ \\
Methanol & $\mathrm{N} / \mathrm{A}$ & $\mathrm{N} / \mathrm{A}$ \\
Water & $\mathrm{N} / \mathrm{A}$ & $\mathrm{N} / \mathrm{A}$ \\
5-Fluorouracil & $37.30 \pm 6.75(0.26)$ & $60.00 \pm 14.14(0.16)$ \\
\end{tabular}

Data are presented as the mean \pm standard deviation following 3 independent experiments. $\mathrm{IC}_{50}$, half maximal inhibitory concentration; SI, selectivity index; N/A, not available.

Table II. Effect of $S$. crispa stem hexane extract on cell cycle progression of HepG-2 cells.

\begin{tabular}{lrrr}
\hline & \multicolumn{2}{c}{ Percentage of cells } & \\
\cline { 2 - 3 } Cell cycle phase & \multicolumn{1}{c}{ Control } & Stem hexane & P-value \\
\hline Sub-G & $0.79 \pm 0.01$ & $0.41 \pm 0.01$ & 0.017 \\
$\mathrm{G}_{0} / \mathrm{G}_{1}$ & $60.68 \pm 1.22$ & $71.16 \pm 0.68$ & 0.009 \\
$\mathrm{~S}$ & $2.22 \pm 0.05$ & $1.80 \pm 0.01$ & 0.008 \\
$\mathrm{G}_{2} / \mathrm{M}$ & $35.37 \pm 0.71$ & $26.13 \pm 0.25$ & 0.003 \\
\hline
\end{tabular}

Data are presented as the mean \pm standard deviation following 3 independent experiments. P-values were determined using the t-test in which the stem hexane-treated group was compared with the control group.

Table III. Effect of S. crispa stem hexane extract on cell cycle progression of MDA-MB-231 cells.

\begin{tabular}{lccc}
\hline & \multicolumn{2}{c}{ Percentage of cells } & \\
\cline { 2 - 3 } Cell cycle phase & Control & Stem hexane & P-value \\
\hline Sub-G & $0.56 \pm 0.59$ & $5.04 \pm 3.44$ & 0.181 \\
$\mathrm{G}_{0} / \mathrm{G}_{1}$ & $70.25 \pm 9.68$ & $57.86 \pm 10.23$ & 0.270 \\
$\mathrm{~S}$ & $0.94 \pm 0.86$ & $8.57 \pm 8.02$ & 0.293 \\
$\mathrm{G}_{2} / \mathrm{M}$ & $28.31 \pm 8.29$ & $28.98 \pm 13.75$ & 0.956 \\
\hline
\end{tabular}

Data are presented as the mean \pm standard deviation following 3 independent experiments. P-values were determined using the t-test in which the stem hexane-treated group was compared with the control group. 
A



$\mathrm{C}$

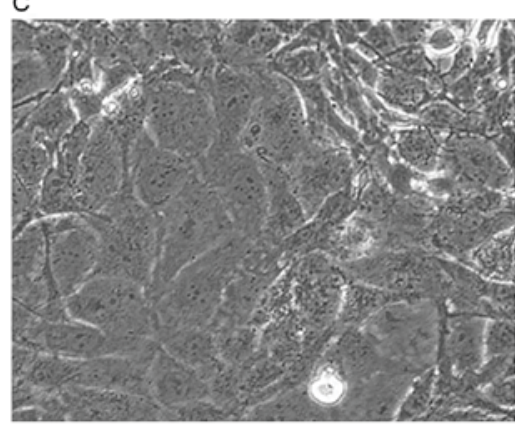

B

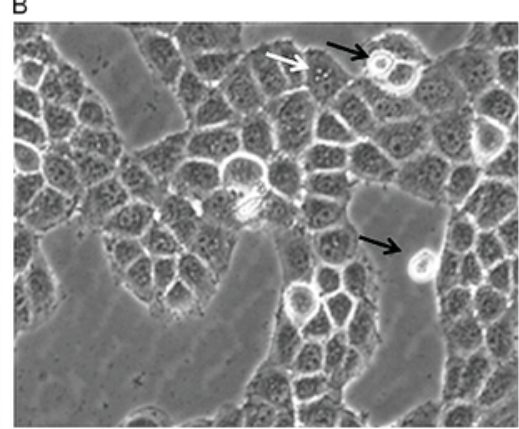

D

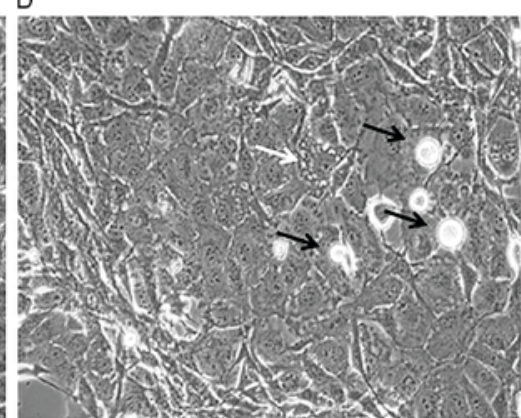

Figure 2. Microscopic observation of (A) untreated control and (B) treated HepG-2 liver cancer cells, and (C) untreated control and (D) treated MDA-MB-231 breast cancer cells. The cells were treated with the predetermined half maximal inhibitory concentration of Strobilanthes crispa stem hexane extract $(38.8 \mu \mathrm{g} / \mathrm{ml}$ for HepG-2 cells; $42.5 \mu \mathrm{g} / \mathrm{ml}$ for MDA-MB-231 cells) for $72 \mathrm{~h}$. The cells were then observed under an inverted microscope (magnification, $\mathrm{x} 200$ ). The white arrow indicates vacuolation of cells and the black arrows indicate floating dead cells.

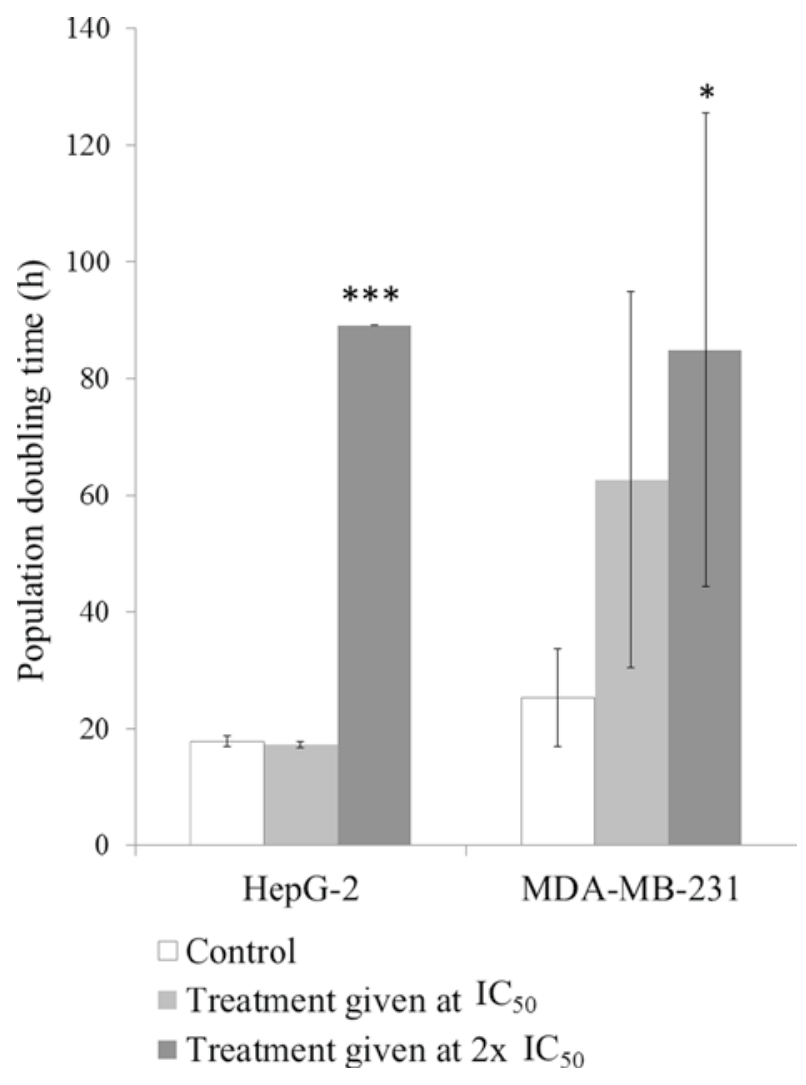

Figure 3. Effects of Strobilanthes crispa stem hexane extract on the cell doubling time of HepG-2 liver cancer and MDA-MB-231 breast cancer cells. Cells were treated with two different concentrations of stems hexane extract (38.8 and $77.6 \mu \mathrm{g} / \mathrm{ml}$ for HepG-2 cells; 42.5 and $85 \mu \mathrm{g} / \mathrm{ml}$ for MDA-MB-231 cells) for $72 \mathrm{~h}$, and the number of cells was counted to determine the cell doubling time. Data are presented as the mean \pm standard deviation following 3 independent experiments. ${ }^{*} \mathrm{P}<0.05$ and ${ }^{* * *} \mathrm{P}<0.001$, compared with the untreated control. $\mathrm{IC}_{50}$, half maximal inhibitory concentration.

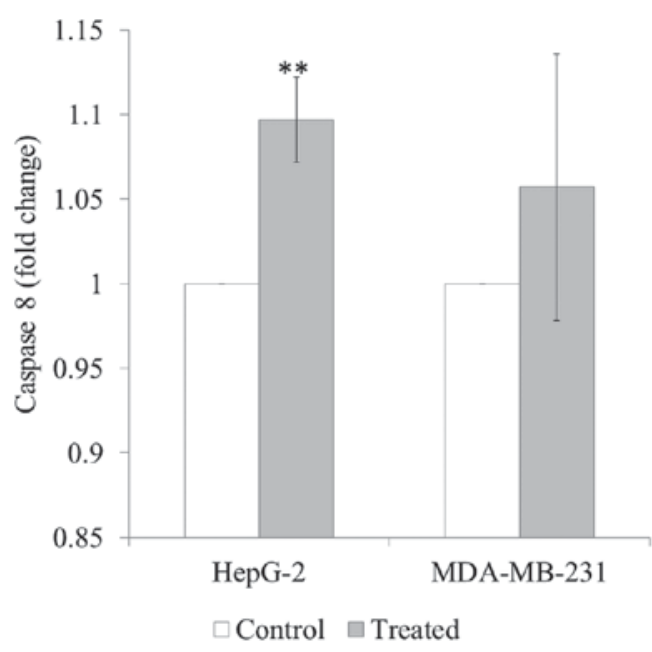

Figure 4. Caspase-8 activity in HepG-2 liver cancer and MDA-MB-231 breast cancer cells following treatment with Strobilanthes crispa stem hexane extract for $72 \mathrm{~h}$. The cancer cells were treated with the extract at their respective half maximal inhibitory concentrations extract $(38.8 \mu \mathrm{g} / \mathrm{ml}$ for HepG-2 cells; $42.5 \mu \mathrm{g} / \mathrm{ml}$ for MDA-MB-231 cells), and the fluorescent expression of caspase- 8 was measured. Data are presented as the mean \pm standard deviation following 3 independent experiments. ${ }^{* *} \mathrm{P}<0.01$, compared with the untreated control.

due to the consistently high mortality rate associated with cancer (28). Therefore, the identification of novel potential anti-cancer therapeutic agents is warranted to provide more treatments options. Natural products serve as a valuable source that offer cytotoxic properties, and have gained significant recognition for their role in the management of cancer. The present study evaluated the anticancer effects of 
S. crispa extracts on HepG-2 liver cancer and MDA-MB-231 breast cancer cells.

An MTT assay was used in the present study to screen the plant extracts for their anti-cancer properties. As demonstrated by the MTT assay LH, LEA, LC, SH and SC reduced cell viability in a concentration-dependent manner in both cell lines. Previous studies have revealed that $S$. crispa extracts are able to kill liver and breast cancer cells (22-24,29). For example, the chloroform extract of S. crispa was demonstrated to possess cytotoxic effects against HepG-2 cells $(22,23)$, while the methanolic extract exhibited strong cytotoxicity on MDA-MB-231 and HepG-2 cells (22). Furthermore, the ethanolic extract (29) and a sub-fraction of the dichloromethane extract of $S$. crispa (24) demonstrated the ability to consistently kill breast cancer cells. Notably, the $\mathrm{IC}_{50}$ values obtained in the present study were higher compared with that in the previous studies mentioned. For instance, Asmah et al (22) identified the $\mathrm{IC}_{50}$ value of the $S$. crispa chloroform extract in HepG-2 cells to be $28 \mu \mathrm{g} / \mathrm{ml}$, while the present study reported an $\mathrm{IC}_{50}$ value of $175.7 \mu \mathrm{g} / \mathrm{ml}$. The methanolic extracts demonstrated no cytotoxic effect on HepG-2 and MDA-MB-231 cells in the present study, but Asmah et al (22) reported that the extract inhibited the growth of the cells with $\mathrm{IC}_{50}$ values of 29.3 and $27.2 \mu \mathrm{g} / \mathrm{ml}$, respectively (22). These contradicting observations may be due to the differences in the geographical areas from which the plants were collected. In fact, a study by Chinkwo et al (30) reported that the bioactivity of extracts from the medicinal plant Sutherlandia frutescens that was collected from different areas varied so much that only plants grown in a specific province exhibited a chemotherapeutic effect. Differences in environmental factors, including soil composition and temperature may influence the production of the bioactive compounds in the plants (31). In addition, the maturity of plants may influence the amount of bioactive compounds produced; generally older plants accumulate a greater amount of content (19).

Among the extracts tested, the hexane extract from the stem of $S$. crispa demonstrated the most potent cytotoxic effect with the lowest $\mathrm{IC}_{50}$ values in the current study. This suggests that the anti-cancer compounds are extractable by hexane, a hydrophobic solvent. Previous studies have revealed that hexane is useful for the extraction of stigmasterol (32-34) and $\beta$-sitosterol (33-36). Stigmasterol and $\beta$-sitosterol extracted from $S$. crispa have been demonstrated to possess anti-cancer effects on liver, breast, and colon carcinoma (22). Other anti-cancer compounds that may be extracted include alkaloids and tannins (20), which have been documented to exhibit anti-cancer properties (37-40). In order to identify the compounds responsible for the anti-cancer effects, further studies on the isolation and purification of the bioactive compounds from $S$. crispa are required.

SI, an indicator of the safety of drug use, was determined for the compounds investigated in the present study. A compound is considered to have high selectivity towards cancer cells if the SI value is $>3$ (26). In the present study, all SI values determined were $<3$, except for $\mathrm{SC}$, indicating the effect of the extracts was not specific to the cancer cells as they were also killing the normal cells. Furthermore, the anti-cancer drug, 5-Fu also demonstrated poor selectivity for tumouricidal activity $(41,42)$. The non-selectiveness of compounds may impose severe side effects on patients with cancer, as they are capable of damaging healthy cells (43). In the current study, SC possessed a relatively high SI value, indicating that it may cause less side effects compared with the other extracts evaluated. In order to improve the selectivity of a compound towards cancer cells, drug modification can be performed (44). Strategies to improve the affinity towards target cells and at the same time lower the affinity towards off-target molecules should be considered (45). Previously, a number of antiepileptic drugs, including levetiracetam, carbamazepine and felbamate, have undergone drug modification to improve their tolerability and efficacy (46). Thus, drug modification to increase the selectively of SH to cancer cells may be an ideal option to further improve its anticancer potency and limit the side effects.

Treatment with $\mathrm{SH}$ was observed to delay the doubling time of HepG-2 and MDA-MB-231 cells in the current study. The cell cycle analysis demonstrated that HepG-2 cells were arrested at the $G_{0} / G_{1}$ phase, indicating that $S H$ inhibited liver cancer cell growth through cell cycle modulation. However, no significant changes in the cell cycle phases were reported in MDA-MB-231 cells. Thus, the reduction in MDA-MB-231 cell proliferation was independent of cell cycle progression and may be attributed to other mechanisms.

Cell apoptosis, an important event in controlling the programmed cell death, may serve an important role in the SH-mediated cytotoxicity observed in the current study. This is evident through the presence of cytoplasmic vacuolation in the HepG-2 and MDA-MB-231 cells, which is a typical feature of apoptosis $(47,48)$. Cell apoptosis is an autonomous dismantled process, which removes individual cell components while avoiding inflammation that usually occurs during necrosis. Thus, apoptosis is only limited to single cells and does not affect normal adjacent cells (49). In cancer studies, induction of apoptosis and inhibition of cellular proliferation are considered as imperative properties in chemoprevention and chemotherapy (50-52). To further confirm the apoptotic activity of $\mathrm{SH}$, caspase activation was determined in the present study.

Caspases can be activated through the intrinsic or extrinsic signalling pathway. Mitochondrial integrity is disrupted by cellular stress in the intrinsic pathway while stimulation of death receptors in the plasma membrane is initiated in the extrinsic pathway (53). In response to cellular stress, the initiator caspases (caspase-2, -8, -9 and -10) cleave and activate the effector caspases (caspase-3, -6 and -7 ); in turn the effector caspases execute the apoptotic process (54). The present study demonstrated that $\mathrm{SH}$ significantly activated caspase- 8 in HepG-2 but not MDA-MB-231 cells.

Taken together, the results of the present study demonstrated that $\mathrm{SH}$ induced cytotoxicity and reduced cell proliferation in HepG-2 cells through cell cycle modulation and caspase- 8 activation. However, the anti-cancer effect of $\mathrm{SH}$ was independent of cell cycle and caspase- 8 activation in MDA-MB-231 cells. This suggests that $\mathrm{SH}$ exhibited cytotoxic effects in MDA-MB-231 cells via other mechanisms. One of the possible mechanisms could be due to the down-regulation of c-myc gene expression (23). C-myc oncogene has been verified to account for the growth and progression of breast cancer in hormone-dependent and -independent breast cancer 
cell lines (55). Other possible mechanisms that may be involved include the p53-dependent signalling pathway (56), tumour necrosis factor-related apoptosis-inducing ligand mechanism (57) and p73-dependent signalling pathway (58). Hence, further studies investigating these mechanisms are warranted to confirm the mechanism of action of SH on the MDA-MB-231 cell line.

In conclusion, $S$. crispa extracts were revealed to exert strong anti-cancer effects on liver and breast carcinoma cells. Among the extracts tested, the SH extract demonstrated the most potent activity and could be further developed as a potential anti-cancer therapeutic drug in the future.

\section{Acknowledgements}

The present study was supported by the International Medical University, Kuala Lumpur, Malaysia [grant no. BMSc I01/09 (03) 2011].

\section{References}

1. Sunilson AJ, Rejitha G, Anandarajagopal K, Das A, Muthappan M and Promwichit P: Cytotoxic effect of Cayratia carnosa leaves on human breast cancer cell lines. Int J Cancer Res 5: 115-122, 2009.

2. Perz JF, Armstrong GL, Farrington LA, Hutin YJ and Bell BP: The contributions of hepatitis $\mathrm{B}$ virus and hepatitis $\mathrm{C}$ virus infections to cirrhosis and primary liver cancer worldwide. J Hepatol 45: 529-538, 2006.

3. El-Serag HB: Epidemiology of hepatocellular carcinoma in USA. Hepatol Res 37 (Suppl 2): S88-S94, 2007.

4. Röcken C and Carl-McGrath S: Pathology and pathogenesis of hepatocellular carcinoma. Dig Dis 19: 269-278, 2001.

5. Sezgin C: Arsenic trioxide has additive cytotoxic effects on MCF-7 breast cancer cell line with taxanes. Turkish J Med Sci 32: 439-444, 2002.

6. Park S, Bae J, Nam BH and Yoo KY: Aetiology of cancer in Asia. Asian Pac J Cancer Prev 9: 371-380, 2008.

7. Ziegler RG, Anderson WF and Gail MH: Increasing breast cancer incidence in China: The numbers add up. J Natl Cancer Inst 100: 1339-1341, 2008.

8. Kelsey JL and Bernstein L: Epidemiology and prevention of breast cancer. Annu Rev Public Health 17: 47-67, 1996.

9. Kelsey JL, Gammon MD and John EM: Reproductive factors and breast cancer. Epidemiol Rev 15: 36-47, 1993.

10. Hulka BS and Stark AT: Breast cancer: Cause and prevention. Lancet 346: 883-887, 1995.

11. Wang S, Liu Q, Zhang Y, Liu K, Yu P, Liu K, Luan J, Duan H, Lu Z, Wang F, et al: Suppression of growth, migration and invasion of highly-metastatic human breast cancer cells by berbamine and its molecular mechanisms of action. Mol Cancer 8: 81, 2009.

12. Beer TM and Bubalo JS: Complications of chemotherapy for prostate cancer. Semin Urol Oncol 19: 222-230, 2001.

13. Leonard RC, Williams S, Tulpule A, Levine AM and Oliveros S: Improving the therapeutic index of anthracycline chemotherapy: Focus on liposomal doxorubicin (Myocet). Breast 18: 218-224, 2009.

14. Wonders KY and Reigle BS: Trastuzumab and doxorubicin-related cardiotoxicity and the cardioprotective role of exercise. Integr Cancer Ther 8: 17-21, 2009.

15. Goldstein MS: Complementary and Alternative Medicine. J Psychosoc Oncol 21: 1-212, 2003.

16. Chan LL, George S, Ahmad I, Gosangari SL, Abbasi A, Cunningham BT and Watkin KL: Cytotoxicity effects of Amoora rohituka and chittagonga on breast and pancreatic cancer cells. Evid Based Complement Alternat Med 2011: 860605, 2011.

17. Sunarto PA: Materia Medica Indonesia. 1st edition. Penerbitan Directorat Jenderal Pengawasan Obat dan Makanan, Jakarta, pp95-99, 1977.

18. Burkill I, Birtwistle W, Foxworthy F, Scrivenor J and Watson J: A dictionary of the economic products of the Malay Peninsula. 1st edition. Published on behalf of the governments of the Straits settlements and Federated Malay states by the Crown agents for the colonies, London, pp2086-2087, 1935.
19. Abu Bakar MF, Teh AH, Rahmat A, Othman F, Hashim N and Fakurazi S: Antiproliferative properties and antioxidant activity of various types of Strobilanthes crispus tea. Int J Cancer Res 2: $152-158,2006$

20. Ismail M, Manickam E, Danial AM, Rahmat A and Yahaya A: Chemical composition and antioxidant activity of Strobilanthes crispus leaf extract. J Nutr Biochem 11: 536-542, 2000.

21. Asmah R, Susi E, Patimah I, Taufiq Yap YH and Mohd Fadzelly AB: Chemical constituents, antioxidant activity and cytotoxic effects of essential oil from Strobilanthes crispus and Lawsonia inermis. J Biol Sci 6: 1005-1010, 2006.

22. Asmah R, Susi E, Abdah MA, Patimah I, Taufiq Yap YH and Mohd Fadzelly AB: Anticarcinogenic properties of Strobilanthes crispus extracts and its compounds in vitro. Int J Cancer Res 2: 47-49, 2006.

23. Susi E, Asmah R, Patimah I and Taufiq-Yap YH: Comparing of the cytotoxicity properties and mechanism of Lawsonia inermis and Strobilanthes crispus extract against several cancer cell lines. J Med Sci 7: 1098-1102, 2007.

24. Yaacob NS, Hamzah N, Nik Mohamed Kamal NN, Zainal Abidin SA, Lai CS, Navaratnam V and Norazmi MN: Anticancer activity of a sub-fraction of dichloromethane extract of Strobilanthes crispus on human breast and prostate cancer cells in vitro. BMC Complement Altern Med 10: 42, 2010

25. Koh RY, Sim YC, Toh HJ, Liam LK, Ong RS, Yew MY, Tiong YL, Ling AP, Chye SM and Ng KY: Cytotoxic and apoptogenic effects of Strobilanthes crispa Blume extracts on nasopharyngeal cancer cells. Mol Med Rep 12: 6293-6299, 2015.

26. Mahavorasirikul W, Viyanant V, Chaijaroenkul W, Itharat A and Na-Bangchang K: Cytotoxic activity of Thai medicinal plants against human cholangiocarcinoma, laryngeal and hepatocarcinoma cells in vitro. BMC Complement Altern Med 10: $55,2010$.

27. Schoene NW and Kamara KS: Population doubling time, phosphatase activity, and hydrogen peroxide generation in Jurkat cells. Free Radic Biol Med 27: 364-369, 1999.

28. Jemal A, Siegel R, Ward E, Murray T, Xu J and Thun MJ: Cancer statistics, 2007. CA Cancer J Clin 57: 43-66, 2007.

29. Chong HZ, Rahmat A, Yeap SK, Md Akim A, Alitheen NB, Othman F and Gwendoline-Ee CL: In vitro cytotoxicity of Strobilanthes crispus ethanol extract on hormone dependent human breast adenocarcinoma MCF-7 cell. BMC Complement Altern Med 12: 35, 2012.

30. Chinkwo KA: Sutherlandia frutescens extracts can induce apoptosis in cultured carcinoma cells. J Ethnopharmacol 98: 163-170, 2005.

31. Wink M: Functions in plants secondary metabolites and their exploration in biotechnology. Sheffield Academic Press, United Kingdom, pp188-2731, 1999.

32. Ahmad A, Alkarkhi AFM, Hena S and Khim LH: Extraction, separation and identification of chemical ingredients of Elephantopus Scaber L. using factorial design of experiment. Int J Chem 1, 2009.

33. Ahmed Y, Rahman S, Akhtar P, Islam F, Rahman M and Yaakob Z: Isolation of steroids from n-hexane extract of the leaves of Saurauia roxburghii. Int Food Res J 20: 2939-2943, 2013.

34. Saludes JP, Garson MJ, Franzblau SG and Aguinaldo AM: Antitubercular constituents from the hexane fraction of Morinda citrifolia Linn. (Rubiaceae). Phytother Res 16: 683-685, 2002.

35. Panal S, Urip H, Pandapotan $M$ and Tonel B: Isolation of $\beta$-sitosterol from n-hexane extract of Picria fel-terrae Lour. leave and study of its antidiabetic effect in alloxan induced diabetic mice. Int J PharmTech Res 6: 137-141, 2014.

36. Saiin C, Rattanajak R, Kamchonwongpaisan S, Ingkaninan $K$, Sukontason K, Baramee A and Sirithunyalug B: Isolation and in vitro antimalarial activity of hexane extract from Thai Picrasma javanica B1 stembark. Southeast Asian J Trop Med Public Health 34 (Suppl 2): S51-S55, 2003.

37. Kabashima H, Miura N, Shimizu M, Shinoda W, Wang X, Wang Z, Takahashi S, Harada T, Maruyama H, Tashiro S, et al: Preventive impact of alkaloids with anti-cancer effect extracted from natural herb and the derivatives. WebmedCentral Prev Med 1: WMC00519, 2010.

38. Lu JJ, Bao JL, Chen XP, Huang M and Wang YT: Alkaloids isolated from natural herbs as the anticancer agents. Evid Based Complement Alternat Med 2012: 485042, 2012.

39. Marzouk MS, Moharram FA, Mohamed MA, Gamal-Eldeen AM and Aboutabl EA: Anticancer and antioxidant tannins from Pimenta dioica leaves. Z Naturforsch C 62: 526-536, 2007. 
40. Gomes de Melo J, de Sousa Araújo TA, Thijan Nobre de Almeida e Castro V, Lyra de Vasconcelos Cabral D, do Desterro Rodrigues M, Carneiro do Nascimento S, Cavalcanti de Amorim EL and de Albuquerque UP: Antiproliferative activity, antioxidant capacity and tannin content in plants of semi-arid northeastern Brazil. Molecules 15: 8534-8542, 2010.

41. Khanna A, Walker GR,Livingstone AS, ArheartKL, Rocha-Lima C and Koniaris LG: Is adjuvant 5-FU-based chemoradiotherapy for resectable pancreatic adenocarcinoma beneficial? A meta-analysis of an unanswered question. J Gastrointest Surg 10: 689-697, 2006.

42. Kurt E, Kurt M, Kanat O, Cetintas SK, Aygun S, Palazoglu T, Ozkan L, Evrensel T, Kaya E and Manavoglu O: Phase II study of induction chemotherapy with gemcitabine plus 5-fluorouracil followed by gemcitabine-based concurrent chemoradiotherapy for unresectable locally advanced pancreatic cancer. Tumori 92: 481-486, 2006

43. Widakowich C, de Castro G Jr, de Azambuja E, Dinh P and Awada A: Review: Side effects of approved molecular targeted therapies in solid cancers. Oncologist 12: 1443-1455, 2007.

44. Huggins DJ, Sherman W and Tidor B: Rational approaches to improving selectivity in drug design. J Med Chem 55: 1424-1444, 2012.

45. Kawasaki Y and Freire E: Finding a better path to drug selectivity. Drug Discov Today 16: 985-990, 2011.

46. Landmark CJ and Johannessen SI: Modifications of antiepileptic drugs for improved tolerability and efficacy. Perspect Medicin Chem 2: 21-39, 2008.

47. Kerr JF, Wyllie AH and Currie AR: Apoptosis: A basic biological phenomenon with wide-ranging implications in tissue kinetics. Br J Cancer 26: 239-257, 1972
48. Syam S, Abdul AB, Sukari MA, Mohan S, Abdelwahab SI and Wah TS: The growth suppressing effects of girinimbine on HepG2 involve induction of apoptosis and cell cycle arrest. Molecules 16: 7155-7170, 2011

49. Elmore S: Apoptosis: A review of programmed cell death Toxicol Pathol 35: 495-516, 2007.

50. Sun SY, Hail N Jr and Lotan R: Apoptosis as a novel target for cancer chemoprevention. J Natl Cancer Inst 96: 662-672, 2004.

51. Wong RS: Apoptosis in cancer: From pathogenesis to treatment. J Exp Clin Cancer Res 30: 87, 2011.

52. Hassan M, Watari H, AbuAlmaaty A, Ohba Y and Sakuragi N: Apoptosis and molecular targeting therapy in cancer. Biomed Res Int 2014: 150845, 2014

53. Hengartner MO: The biochemistry of apoptosis. Nature 407: 770-776, 2000

54. Cullen SP and Martin SJ: Caspase activation pathways: Some recent progress. Cell Death Differ 16: 935-938, 2009.

55. Shiu RP, Watson PH and Dubik D: c-myc oncogene expression in estrogen-dependent and -independent breast cancer. Clin Chem 39: 353-355, 1993.

56. Shen Y and White E: p53-dependent apoptosis pathways. Adv Cancer Res 82: 55-84, 2001.

57. Zhang L and Fang B: Mechanisms of resistance to TRAIL-induced apoptosis in cancer. Cancer Gene Ther 12: 228-237, 2005.

58. Ramadan S, Terrinoni A, Catani MV, Sayan AE, Knight RA, Mueller M, Krammer PH, Melino G and Candi E: p73 induces apoptosis by different mechanisms. Biochem Biophys Res Commun 331: 713-717, 2005. 